\title{
DIVERSIFIKASI PRODUK OLAHAN CABAI MERAH KERITING SEBAGAI ALTERNATIF PENANGANAN PASCA PANEN CABAI MERAH DI KECAMATAN CURUP UTARA KABUPATEN REJANG LEBONG
}

\section{PROCESSING PRODUCT DIVERSIFICATION OF RED CHILLI AS AFTER HARVEST HANDLING ALTERNATIVE IN REJANG LEBONG}

\author{
Oleh: \\ Neti Kesumawati dan Rita Hayati \\ karyaaza@yahoo.co.id
}

\begin{abstract}
ABSTRAK
Pelatihan ini dilaksanakan di Kelompok Wanita Tani Teratai dan Mawar Kecamatan Curup Utara Kabupaten Rejang Lebong. Kelompok wanita tani ini mempunyai usaha bercocok tanam cabai. Hasil panen biasanya dijual dalam bentuk segar tanpa ada pengelolaan terlebih dahulu. Keterbatasan pengetahuan dan keterampilan pengolahan pasca panen cabai membuat mereka terpaksa menjualnya dalam bentuk segar. Tujuan dilaksanakannya pelatihan ini adalah (1) Agar kelompok wanita tani memiliki pengetahuan dan keterampilan untuk memperpanjang masa simpan cabai merah keriting; (2) mampu mengurangi resiko kegagalan dalam usaha cabai merah keriting, terutama pada saat terjadinya penimbunan hasil panen; (3) mampu memanfaatkan teknologi pengolahan cabai merah menjadi tepung cabai, abon cabai dan saos cabai serta mampu menjadikannya sebagai usaha dalam meningkatkan nilai tambah cabai merah keriting, terutama disaat harga anjlok di pasaran. Metode yang digunakan dalam pelatihan ini terdiri dari tiga metode (1) Pendidikan dan penyuluhan tentang arti pentingnya memperpanjang masa simpan tanaman hortikultura dan pengetahuan tentang pembuatan tepung, abon dan saos berbahan baku cabai merah keriting; (2) Pelatihan tentang proses pembuatan tepung, abon dan saos berbahan baku cabai merah keriting; (3) Pendampingan kelompok wanita tani dalam memproduksi cabai kering, abon dan cabe kering yang dihasilkan menjadi usaha pokok mereka. Hasil pelatihan ini adalah pengolahan cabai merah keriting dengan menggunakan teknologi yang sederhana mampu menghasilkan produk olahan dalam bentuk abon cabai, tepung cabai dan saos cabai yang mempunyai citarasa khas daerah Kecamatan Curup utara. Selain itu, pemanfaatan teknologi sederhana ini bisa memperpanjang masa simpan cabai sehinggga dapat menjadi peluang bisnis yang sangat menjanjikan ketika harga jual cabai meningkat tajam.
\end{abstract}

Kata Kunci: Hortikultura, Umur Simpan, Cabe Kering, Abon Cabe, Saos Cabe

\section{PENDAHULUAN}

Kecamatan Curup Utara adalah salah satu delapan kecamatan yang ada di Kabupaten Rejang Lebong dengan luas daerah $395 \mathrm{Ha}$ atau hampir 0,26 \% dari luasan kabupaten secara keseluruhan. Ibu kecamatan berjarak $3 \mathrm{~km}$ dari ibu kabupaten dan $88 \mathrm{~km}$ 
dari ibu kota Propinsi Bengkulu. Konturnya berbukit, suhu rata-rata $23-32^{\circ} \mathrm{C}$ dengan tingkat kelembaban $40-80 \%$. Kondisi geografi yang dikeliling oleh perbukitan, seperti pengunungan bukit Barisan, bukit Basa dan timur bukit Kaba telah menjadikan tanah di sekitarnya sangat subur sekali sehingga cocok sekali untuk usaha pertanian. Banyak sekali hasil-hasil pertanian yang berasal dari daerah ini, baik tanaman hortikultura maupun tanaman pangan. Oleh karena itu, daerah Kecamatan Curup Utara terkenal sebagai salah satu sentra pertanian di Kabupaten Rejang Lebong dan Propinsi Bengkulu secara menyeluruh serta pemasok sayuran dan buah-buahan di daerah sekitarnya bahkan ke luar kota, seperti kota Bengkulu, Argamakmur, Lubuklinggau dll. Salah satu hasil pertanian yang menonjol dan menjadi salah satu unggulan daerah ini adalah cabai merah keriting, dimana luas tanam pada tahun 2014 lalu 34 ha, dengan produksi 271,5 ton (BPP, 2015).

Cabai merah keriting yang mempunyai ukuran agak kecil, rasanya sangat pedas, banyak mengandung gizi, diantaranya kalori, protein, lemak, kabohidarat, kalsium, vitamin A, B1 dan vitamin C (Nurfalach, 2010). Selain digunakan untuk kebutuhan rumah tangga, cabe juga dapat digunakan untuk keperluan industri diantaranya, industri bumbu masakan, industri makanan dan industri obat-obatan atau jamu. Hal ini merupakan peluang bisnis yang sangat menguntungkan bagi petani dan pedagang cabe sehingga memiliki potensi untuk meningkatkan perekonomian mereka. Irfansyah (2014), sebenarnya semua jenis sayuran dan buah-buahan dapat dijadikan bisnis yang menguntungkan untuk lima tahun ke depan. Terbukti pada tahun 2014, disaat harga cabe melonjak sampai pada tingkat harga Rp. 90.000 (Tohamaksun, 2014), banyak petani cabe yang sempat membeli rumah, mobil, mendaftar haji, dll. Kesempatani untuk memperbaiki taraf hidup ini tidak berlangsung lama, karena banyak cabe dari luar Kota Curup (Lampung, Jambi, dan beberapa kota di Sumatera Selatan) membanjiri pasar-pasar Kota Curup dan lebih diminati konsumen karena harganya lebih murah dan kualitasnya lebih baik dan kadar airnya lebih rendah. Keadaan ini sangat memprihatinkan sekali karena berimbas pada menurunnya daya jual sehingga terjadi penumpukan hasil panen dan pembusukan cabe. Permasalahan di atas harus menjadi perhatian semua pihak agar bisa mencari solusi yang terbaik sehingga petani mampu memanfaatkan peluang sekaligus untuk memecahkan masalah yang dihadapi. Salah satu upaya yang ditempuh untuk membantu petani agar dapat memperpanjang masa simpan cabe adalah penerapan teknologi pengolahan cabe menjadi produk pangan, seperti cabe kering, abon dan saos. Di Kecamatan Curup Utara terdapat terdapat banyak kelompok tani, diantaranya adalah kelompok tani khusus wanita. Di Desa Perbo ibu-ibu petani berhimpun dalam Kelompok Wanita Tani Mawar. Kelompok ini terbentuk pada tangga 8 Desember 2012, dengan jumlah anggota saat ini tercatat $30 \mathrm{KK}$ (kepala keluarga). Disamping bertanam sayur-mayur, buah-buahan dan palawija, anggota kelompok tani ini juga memiliki usaha sampingan, yaitu pembuatan gula merah dari tanaman enau. Masingmasing anggota kelompok bisa menghasilkan gula merah sebanyak $10 \mathrm{Kg}$ dalam satu minggunya. Sementara di Kelurahan Tunas Harapan, semenjak 5 April 2012 ibu-ibu petani mendirikan Kelompok wanita tani Teratai, dengan jumlah anggota saat ini tercatat 
25 KK (kepala keluarga). Selanjutnya kedua kelompok wanita tani ini dipilih sebagai mitra dengan pertimbangan karena wanita sudah terbiasa dan dianggap lebih telaten dalam kegiatan pengolahan produk pangan.

\section{Permasalahan Mitra}

Cabai merah keriting dalam bentuk segar memiliki daya simpan yang tidak lama akibat kerusakan mikrobiologi/fisiologi karena serangan mikroba Colletrothicum capsici dan kerusakan fisiologis karena proses respirasi buah pada saat penyimpanan (Jumasdan, 2012). Permasalahan dalam usaha budidaya cabai bertambah berat pada saat panen raya karena harga yang rendah dan tidak signifikan dibandingkan biaya produksi yang harus dikeluarkan. Apalagi cabai yang dihasilkan petani di Kecamatan Curup Utara kalah bersaing dengan cabe yang berasal dari Lampung, Jambi dan beberapa kota di Sumatera Selatan yang kualitasnya lebih baik dan lebih murah dan kadar airnya lebih sedikit. Sedangkan petani di daerah ini hanya mengantungkan usahanya pada penjualan cabai dalam bentuk segar atau belum mampu mengolah cabai tersebut menjadi produk pangan yang bisa disimpan lebih lama.

Penjualan cabai dalam bentuk segar memang sangat menjanjikan, dimana keuntungan akan diperoleh dalam waktu tidak terlalu lama jika penjualan berlancar lancar (Yasami, dkk, 2014), Tetapi tidak bisa dipungkiri banyak juga petani cabai gulung tikar akibat membusuknya cabai-cabai yang dijual dalam bentuk segar. Utama (2010), kehilangan air dari produk pertanian dapat berakibat terhadap kehilangan hasil, baik secara kualitatif dan kuantitatif. Kondisi makin diperparah pada saat panen raya produksi melimpah dengan harga relative murah sehingga petani sering mengalami kerugian. Sementara ini, hasil produksi cabai merah keriting di Kecamatan Curup Utara belum termanfaatkan secara optimal karena banyaknya cabai yang membusuk, terutama pada waktu hasil produksi berlimpah ruah. Keterbatasan pengetahuan dan keterampilan menyebabkan mereka sama sekali belum mampu mengolah hasil panen cabai menjadi produk pangan yang bisa memperpanjang masa simpan hasil panen.

Tanaman cabai (Capsicum sp.) berasal dari benua Amerika yang ditemukan pertama kali oleh Christophorus Columbus pada tahun 1490. Tanaman ini sudah dibudidayakan oleh suku Indian untuk keperluan memasak sejak tahun 7000 SM dan mulai diperkenalkan ke benua lain pada tahun 1502. Saat ini, sudah menyebar ke seluruh dunia sebagai salah satu bahan utama makanan, termasuk Indonesia (Nugraheni dan Hera, 2005).

Cabai merupakan tanaman perdu dari famili terong-terongan yang memiliki banyak ragam tipe pertumbuhan dan bentuk buahnya. Diperkirakan di dunia terdapat 20 spesies tanaman cabai yang sebagian besar hidup di negara asalnya (Wardana, 2014).

Secara umum cabai memiliki banyak kandungan gizi dan vitamin. Diantaranya Kalori, Protein, Lemak, Kabohidarat, Kalsium, Vitamin A, B1 dan Vitamin C. Selain digunakan untuk keperluan rumah tangga, cabe juga dapat digunakan untuk keperluan 
industri diantaranya, Industri bumbu masakan, industri makanan dan industri obat-obatan atau jamu (Nurfalach, 2010).

\section{Pascapanen Cabai}

Pemanenan buah cabai pertama dilakukan pada umur 60-75 hari setelah tanam, dengan interval \pm 3-7 hari. Pemilihan buah yang akan dipanen tergantung dengan tujuan pemanenan, seperti: (1) Jika dijual segar dipanen matang,; (2) jika untuk dikirim dengan jarak yang jauh, buah dipanen matang hijau; (3) Jika buah yang akan dikeringkan dipanen setelah matang penuh (Sumarni dan Muharam, 2005).

\section{Abon Cabai}

Tabel 1. Bahan dan peralatan pembuatan abon cabai

\begin{tabular}{cll}
\hline No. & \multicolumn{1}{c}{ Bahan } & \multicolumn{1}{c}{ Peralatan } \\
\hline 1. & Cabe merah & Pisau \\
2. & Cabe rawit merah yang sudah tua & Timbangan \\
3. & Bawang putih & Baskom (bak plastik) \\
4. & Bawang merah & Kompor Gas \\
5. & Ketumbar & Dandang (kukusan) \\
6. & Gula merah sisir halus & Mesin gilingan cabe \\
7. & Garam & Blender (alat penggiling) \\
8. & Bumbu penyedap & Panci sterilisasi \\
9. & & Saringan \\
10 & & Wajan \\
11. & & Sodet (kayu pengaduk) \\
12. & & Corong \\
13. & & Alat penutup botol, botol, pencepit botol \\
\hline
\end{tabular}

Cara Kerja (Nugraheni dan Hera, 2005):

1. Cuci bersih cabe merah dan cabe rawit yang sudah disortasi, kemudian tiriskan.

2. Keringkan kedua jenis cabe yang telah dicuci bersih tadi dengan cara dijemur dibawah sinar matahari secara langsung ataudengan menggunakan oven.

3. Setelah cabe benar-benar kering, tidak mengandung air lagi, maka cabe siap dihaluskan.

4. Haluskan cabe dengan menggunakan mesin penggiling.

5. Setelah cabe halus dan teksturnya ringan, pindahkan cabe ke dalam baskom kering.

6. Haluskan semua bahan bumbu kemudian tumis sampai harum di wajan yang berukuran besar.

7. Masukkan cabe yang sudah halus ke dalam wajan, aduk terus sampai semua bumbu tercampur rata dan sangat kering (tidak berminyak lagi).

8. Diamkan sampai dingin dan abon cabe siap disimpan kedalam wadah yang tertutup rapat.

9. Cuci botol sampai bersih dan rebus dalam air mendidih selama 30 menit 
10.Masukkan abon cabe yang telah dingin ke dalam botol

\section{Cabe Kering}

Tabel 2. Bahan dan peralatan pembuatan cabe kering

\begin{tabular}{cll}
\hline No. & \multicolumn{1}{c}{ Bahan } & \multicolumn{1}{c}{ Peralatan } \\
\hline 1. & Cabe merah keriting & Baskom/ember \\
2. & Natrium metasulfit & Nyiru \\
3. & & Pisau \\
4. & Mesin penggiling cabe \\
5. & Sodet (kayu pengaduk) \\
6. & Corong \\
7. & Alat penutup botol, botol \\
8. & Rak pengering cabai \\
\hline
\end{tabular}

Cara kerja (Nugraheni dan Hera, 2005):

1. Pilihlah cabe yang sudah masak dan bersihkan.

2. Hilangkan tangkai cabe yang sudah dibersihkan dan lakukan pembelahan.

3. Celupkan belahan cabe dalam air panas yang susunya mendekati titik didih $\left(90^{\circ}\right)$ (blanching) selama 60 detik.

4. Agar warna cabe tetap bewarna merah, masukkan Natrium metasulfit $0,2 \%$ kedalam air celupan di atas.

5. Angkat cabe dari perendaman dan tiriskan.

6. Tata cabe yang sudah diangkat dari rendaman di atas nyiru, lalu dijemur di panas matahari sampai benar-benar kering atau setelah kadar air mencapai $12 \%$.

7. Giling cabe yang sudah kering dengan menggunakan hingga menjadi serbuk cabe.

\section{Saos Cabai}

Tabel 3. Bahan dan peralatan pembuatan saos cabai

\begin{tabular}{cll}
\hline No. & \multicolumn{1}{c}{ Bahan } & \multicolumn{1}{c}{ Peralatan } \\
\hline 1. & Tomat merah & Pisau \\
2. & Cabe merah & Timbangan \\
3. & Garam & Baskom (bak plastic) \\
4. & Gula & Kompor \\
5. & Bawang putih + bawang merah & Dandang (kukusan) \\
6. & Bahan pengawet (Na Benzoat & Blender \\
7. & Air secukupnya & Panci sterilisasi \\
8. & & Saringan \\
9. & & Wajan \\
10. & & Sodet (kayu pengaduk) \\
11. & & Corong \\
12. & & Alat penutup botol, botol, pencepit botol \\
\hline
\end{tabular}


Cara kerja (Sinaga, 2010):

1. Pilih cabe dan tomat yang masak, segar dan bersihkan.

2. Kukus semua bahan selama 5 menit dan angkat.

3. Tiriskan dan kupas kulit semua, terutama tomat.

4. Haluskan semua bahan dan bumbu secara terpisah.

5. Saring bahan yang sudah digiling dengan menggunakan saringan 16 mesh (16 lubang perinci).

6. Campur bahan yang sudah disaring dengan semua bumbu dan dimasak.

7. Diamkan sampai dingin dan saos cabe siap disimpan kedalam wadah yang tertutup rapat.

8. Cuci botol sampai bersih dan rebus dalam air mendidih selama 30 menit.

9. Masukkan abon cabe yang telah dingin ke dalam botol.

\section{METODE PENGABDIAN}

Pelatihan ini dibagi menjadi tiga metode:

a. Pendidikan dan Penyuluhan

Untuk menambah wawasan anggota kelompok tani dilakukan melalui pendidikan dan penyuluhan tentang arti pentingnya memperpanjang masa simpan tanaman hortikultura dan pengetahuan tentang pembuatan cabe kering, abon dan saos berbahan baku cabe merah keriting

\section{b. Pelatihan}

Berdasarka permasalahan dan solusi yang telah disepakati, maka anggota kelompok tani sasaran dilatih dalam proses pembuatan cabe kering, abon dan saos berbahan baku cabe merah keriting (cara kerja dan diagram alir pembuatan pada halaman selanjutnya).

Adapun alur pelaksanaan pelatihan program IbM ini dimulai dari, 1) Tahap persiapan, yang terdiri dari tahap: (a) penyiapan bahan administrasi sesuai dengan kebutuhan pelaksanaan sosialisasi; (b) melakukan koordinasi dengan ketua Kelompok Wanita Tani Teratai dan ketua Kelompok Wanita Tani Mawar Kecamatan Curup; (c) menyiapkan materi penyuluhan; (d) menyiapkan jadwal sosialisasi pelatihan dengan perencanaan kegiatan yang telah disepakati; 2) tahap pelaksanaan, yang terdiri dari : (a) melakukan sosialisasi pelatihan pengolahan bahan baku cabe menjadi produk olahan saos cabe, abon cabe dan tepung cabe; (b) diskusi terbatas mengenai penguasaan pengetahuan dan keterampilan tentang pengolahan bahan baku cabe menjadi produk olahan saos cabe, abon cabe, dan tepung cabe, dan 3) tahap evaluasi, yaitu penilaian oleh tim pelaksana terhadap produk olahan saos cabai, abon cabai, dan tepung cabai yang langsung dibuat oleh peserta. 


\section{c. Pendampingan}

Dari hasil kedua tahapan di atas, petani yang sudah dilatih membuat cabe kering, abon dan saos cabe dibimbing dan didampingi dalam memproduksi cabe kering, abon dan cabe kering yang dihasilkan menjadi usaha pokok mereka.

\section{HASIL DAN PEMBAHASAN}

Pelaksanaan kegiatan pengabdian kepada masyarakat "IbM" Kelompok Wanita Tani Curup Utara Rejang Lebong" yaitu Kelompok Wanita Tani Teratai Kelurahan Tunas Harapan dan Kelompok Wanita Tani Mawar Desa Perbo yang mengikutsertakan sebagian dari anggota kelompok wanita. Anggota kelompok wanita tani yang terpilih diharapkan menjadi informan kunci yang akan menyampaikan pengetahuan dan keterampilan yang diterimanya.

\section{Hasil Kegiatan Pengabdian IPTEKS Bagi Masyarakat}

Program yang langsung berhubungan dengan anggota kelompok wanita tani dimulai dengan penyuluhan tentang pengolahan cabe manjadi bermacam produk olahan (pengolahan pascapanen cabe, kekurangan dan kelebihan penjualan cabai dalam bentuk segar maupun cabe yang sudah diolah serta kaitannya dengan pendapatan mereka. Setelah mereka mengerti tentang arti pentingnya penanganan pascapanen, baru dilaksanakan pelatihan tentang pembuatan saos cabe, abon cabe, dan tepung cabe yang kegiatannya diwujudkan dalam bentuk praktek.

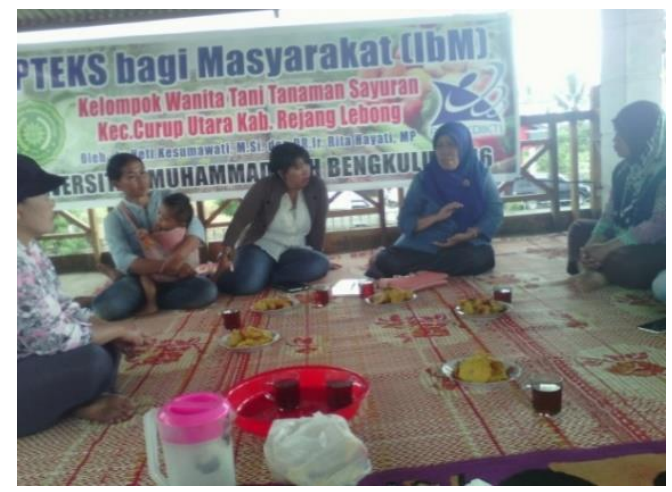

Gambar 1. Penyuluhan dengan kelompok wanita tani

Permasalahan yang dihadapi oleh anggota kelompok wanita tani Teratai dan Mawar yang pada umumnya berusahatani cabe adalah belum termanfaatkannya cabe secara optimal sehingga mengalami pembusukan, terutama pada waktu hasil produksi berlimpah ruah. Keterbatasan pengetahuan dan ketrampilan menyebabkan mereka sama sekali belum mampu mengolah hasil panen cabe menjadi produk olahan yang bisa memperpanjang masa 
simpan hasil panen. Maka dilakukan upaya peningkatan pengetahuan dan ketrampilan serta wawasan mereka dalam pengolahan cabai menjadi produk olahan. Upaya yang dianggap ampuh adalah berupa transfer iptek yang dilakukan berupa sosialisasi, pelatihan, dan pendampingan kepada anggota kelompok wanita tani.

Sosialiasi dihadiri banyak anggota kelompok tani wanita dari beberapa desa yang dijadikan lokasi pengabdian. Hal ini menunjukkan bahwa masyarakat cukup antusias dalam mengikuti kegiatan ini. Demikian juga halnya pelatihan. Para wanita anggota kelompok tani terlihat sangat antusias dalam berpartisipasi langsung melaksanakan praktek pembuatan berbagai jenis produk olahan cabai merah.

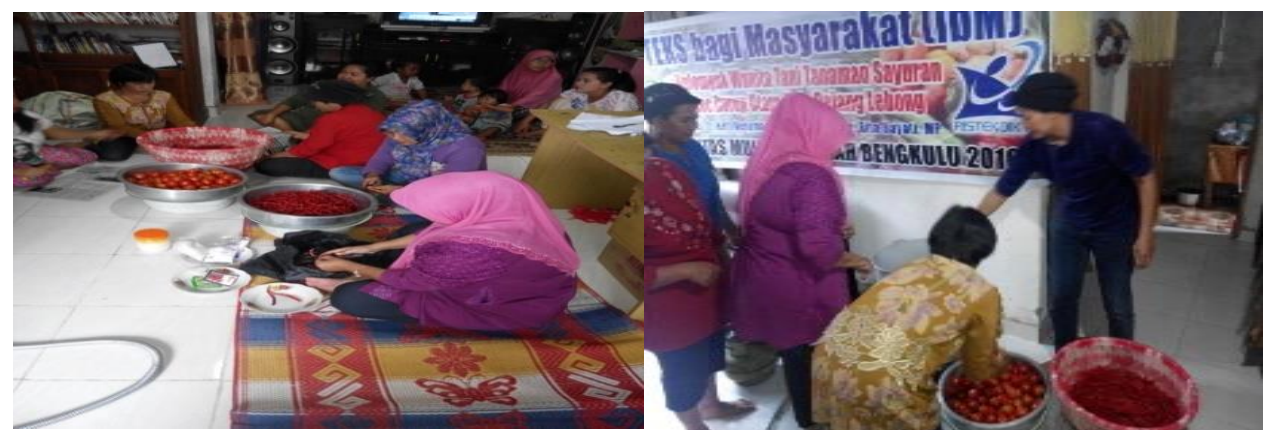

Gambar 2. Pelatihan pembuatan saos cabai pada kelompok Wanita Tani
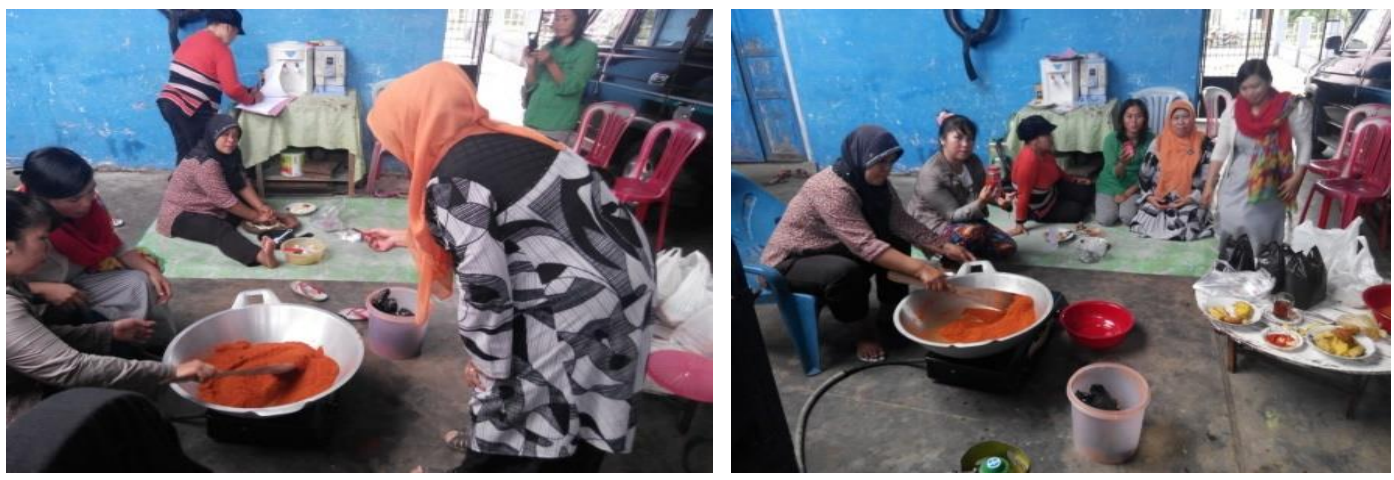

Gambar 3. Pelatihan pembuatan tepung cabe/bubuk cabeaidan abon cabai

\section{Tahap Evaluasi Program}

Untuk mengukur tingkat keberhasilan kegiatan yang telah dilakukan maka akan dilakukan penilaian (evaluasi) terhadap produk olahan cabe (saos cabe, tepung maupun abon cabe) yang langsung dihasilkan oleh kelompok wanita tani tersebut. Penilain ini dilakukan sampai dihasilkan produk olahan yang cocok secara cita rasa.

Berdasarkan hasil evaluasi dapat ditarik kesimpulan bahwa terdapat beberapa manfaat praktis yang diperoleh oleh anggota kelompok wanita tani Teratai dan kelompok wanita tani Mawar Kecamatan Curup melalui sosialisasi pelatihan, yaitu: (1) mereka 
mendapatkan banyak informasi tentang penanganan pascapanen cabe sehingga dapat menciptakan lapangan pekerjaan baru; (2) Para anggota kelompok wanita tani yang menjadi peserta pelatihan memperoleh gambaran tentang usaha baru yang mempunyai prospek yang bagus untuk dikembangkan; (3) Para anggota wanita tani yang menjadi peserta pelatihan juga mendapatkan gambaran tentang arti pentingnya meminimalisir kerugian akibat membusuknya hasil pertanian.

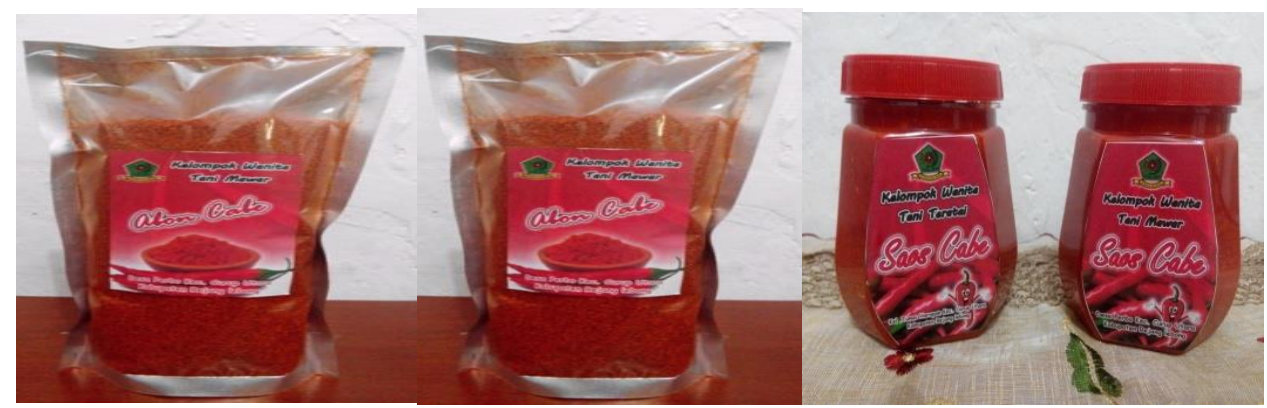

Gambar 4. Abon cabe dan tepung cabe produksi kelompok wanita tani

\section{KESIMPULAN DAN SARAN}

\section{Kesimpulan}

Dari hasil kegiatan pengabdian dapat disimpulkan bahwa pelaksanaan kegiatan pengabdian secara umum memberikan pengetahuan dan keterampilan pengolahan cabe menjadi saos cabe, abon cabe, dan tepung. Hal ini dapat terlihat dari produk yang dihasilkan dari rangkaian kegiatan pelatihan, khususnya pembuatan berbagai produk olahan cabe merah.

\section{Saran}

1. Perlu pendampingan yang lebih lanjut terhadap anggota kelompok wanita tani dalam memproduksi produk olahan cabe

2. Perlu program rintisan lanjutan yang bisa memperkenalkan produk olahan cabe yang lebih bervariasi

3. Bagi kelompok wanita tani berfungsi sebagai informan kunci dalam penyebaran pengetahuan dan ketrampilan tentang pengolahan cabe menjadi produk olahan

\section{DAFTAR PUSTAKA}

BPP, 2015, Laporan Tahunan BPP Kesambe Lama. Curup Timur, Kabupaten Rejang Lebong. 
Irfansyah, T., 2014, Prospek Pengembangan Hortikultura di Indonesia, Jurusan Ilmu Budidaya Pertanian, Program Studi Agroekoteknologi Fakultas Pertanian, Universitas Hasanuddin, Makasar.

Jumasdan, 2012, Studi Pengaruh Penambahan Gas $\mathrm{CO}_{2}$ terhadap Umur Simpan Cabe Keriting (Capsicum annum var) Tanpa Bkanching, Program Studi Ilmu Dan Teknologi Pangan, Jurusan Teknologi Pertanian Fakultas Pertanian Universitas Hasanuddin, Makasar.

Nugraheni, M., Hera, T., 2005, Diversifikasi Cabai Merah Kering sebagai Alternatif Penganganan Pasca Panen Cabai Merah di Kecamatan Sanden Kabupaten Bantul, Yogyakarta.

Nurfalach, 2010, Budidaya Tanaman Cabai Merah (Capsicum annum L.) di UPTD Perbibitan Tanaman Hortikultura Desa Pakopen Kecamatan Bandungan Kabupaten Semarang, Semarang.

Sumarni, N., Dn. Muharam, A., 2005, Budidaya Tanaman Cabai Merah, Balai Penelitian Tanaman Sayuran Bandung, Pusat Penelitian dan Pengembangan Hortikultura, Bandung.

Tohamaksun, 2014, Harga cabai merah di Rejanglebong capai Rp. 90.000,- , Antara News, Bengkulu.

Wardana, M.H., 2014, Budidaya Tanaman Cabai Merah, UPTD Perbibitan Tanaman Hortikultura, Desa Sumberejo Kecamatan Ambulu Kabupaten Jember.

Yasami, I.E., dkk., 2013, Berbisnis Cabai, Universitas Gunadarma. 